\title{
STUDI KEPEMIMPINAN DIGITAL DAN KEPEMIMPINAN KREATIF YANG MEMPENGARUHI INOVASI DI UMKM JATIMULYA BEKASI JAWA BARAT
}

\author{
Nining Widya Lestari \\ Universitas Mitra Karya \\ niningwidyalestari@umika.co.id
}

\begin{abstract}
The purpose of this research is to study the components of digital leadership and creative leadership that affect innovation in 10 SME companies in Bekasi, West Java. By using 90 saturated samples and PLS analysis. The results of the findings of this study are a significant influence between digital leadership and creative leadership on innovation both partially and simultaneously. Thus the management of SMEs must ensure that the process of creating a digital vision, communicating digital vision, implementing digital vision is a must in facing the technological changes of the 21 st century. On the other hand, management must also ensure that the process of creating a creative leadership dimension in imagination, constructing a vision is a guarantor for the formation of levels. innovation in radical extremes.
\end{abstract}

Keywords Innovation, digital leadership, creative leadership

\section{PENDAHULUAN}

Abad ke-21 adalah era ekonomi pengetahuan. Ekonomi berbasis pengetahuan berubah menjadi faktor produksi dan instrumen persaingan untuk mengarahkan kepada pencapaian baru organisasi mana pun diseluruh permukaan bumi (Tong \& Baslom, 2019). Ini semua tentang apa yang bisa dilakukan dengan tekhnologi apa yang diketahui. Semuanya didasarkan pada informasi yang dapat mengubah pengetahuan menjadi produk sekaligus komoditas yang menggiurkan. Ini adalah faktor produksi yang abstrak dan tidak berwujud serta berpotensi menghasilkan inovasi untuk dimasa depan. Fenomena baru ini memaksa kinerja setiap organisasi menggeser pendekatan dari manfaat pragmatisme bisnis belaka menjadi tujuan mulia yang lebih tersosialisasi dengan sempurna (Nayeri \& Rostami, 2016).

Termasuk di UMKM Jatimulya Bekasi . Menciptakan inovasi sebagai salah satu cara untuk membantu kinerja organisasi menuju tantangan eksistensi. Ada tawaran yang kuat untuk menjadi organisasi inovasi bagi institusi, hal ini dapat dilihat dari tujuan kelangsungan hidup, peningkatan kapasitas sumber daya manusia dan tujuan keberlanjutan . 
Niat perubahan organisasi menuju inovasi sejalan dengan konsep dibawah Undang-Undang Pendidikan Nasional sebelumnya di Indonesia serta edisi baru dalam Teknologi Pendidikan di seluruh bangsa menyimpulkan bahwa diperlukan manfaat pengetahuan untuk meningkatkan produktivitas hasil. Dalam melakukannya, inovasi adalah istilah kunci untuk melakukan organisasi untuk memberikan cara alternatif untuk mencapai tujuan.

Hal tersebut diperlukan karena inovasi dapat dilakukan melalui percepatan pengembangan kapabilitas produktif, peningkatan insentif bagi sumber daya manusia untuk menciptakan inovasi yang dapat meningkatkan mutu pendidikan . Tawaran implementasi inovasi dapat sangat membantu institusi pendidikan untuk mencapai tujuan dan mendapatkan standar indeks kinerja yang lebih tinggi. Saat ini, pengembangan institusi pendidikan untuk menjalankan program-program yang dapat meningkatkan inovasi membutuhkan kehadiran pimpinan yang sangat memperhatikan peningkatan tersebut. Dibutuhkan pemimpin yang sangat kuat dalam implementasi, karena kendala lembaga untuk menciptakan inovasi adalah kemauan, kebijakan, dan sistem pendukung untuk bekerja sesuai jalur sasaran visi (Obiekwe, 2018).

Setiap organisasi yang berfokus pada penciptaan dan pengembangan inovasi akan menghadapi masalah, kebutuhan, dan peluang untuk memberikan dampak terhadap pembangunan masyarakat. Sejalan dengan itu, inovasi yang terus berkembang ditetapkan menjadi kompetensi inti organisasi saat ini . Dalam konteks pendidikan tinggi, perguruan tinggi, fakultas dan universitas, manusia sumber daya memainkan peran untuk menyediakan lingkungan belajar terbaik bagi universitas mahasiswa. Hal itu bisa terjadi ketika sumber daya manusia seperti dosen dan tenaga pendidik saling bahu membahu memberikan pelayanan yang terbaik bagi mahasiswa.

Penting bagi perguruan tinggi untuk mendapatkan informasi atau umpan balik yang diperlukan untuk mengevaluasi indeks kinerja. Sebagaimana diketahui bahwa karyawan muda akan menjadi masa depan bangsa yang berperan penting sebagai pemimpin bangsa. Oleh karena itu, penyiapan kapabilitas harus dimulai sejak di awal karir. Karena tantangan yang dihadapi semua personalia ke depan akan berbeda dengan masalah yang terjadi saat ini . Oleh karena itu, kepemimpinan 
sangat penting untuk membantu karyawan menemukan jalan dan berpotensi untuk muncul karena hasil tinggi yang berprestasi benar-benar sesuai dengan harapan atau tujuan industri UMKM.

Di UMKM Bekasi, tantangan untuk menciptakan karyawan yang berkualitas dapat tercermin dari kemampuan karyawan dalam memecahkan masalah tersebut dan mampu mengembangkan kepribadiannya di masyarakat . Hal ini sejalan dengan arah global yang menuntut perubahan hasil pelatihan manajemen internal. Oleh karena itu, institusi pelatihan perlu mengintegrasikan berbagai ilmu dalam manajemen dan pengembangan inovasi sebagai elemen kunci dalam membangun kompetensi. Institusi UMKM sangat penting dalam menghasilkan karyawan digital untuk memenuhi kebutuhan pasar kerja dan masyarakat. Dengan demikian, karyawan digital memiliki kualifikasi dengan standar kemampuan berinovasi.

Pengertian peran penting kepimimpinan digital dimulai dari pengaruh perkembangan pribadi karyawan yang terbentuk dari interaksi antara pemimpin digital dan karyawannya - Pemimpin digital harus mampu memfasilitasi kebutuhan karyawan dengan baik. Dalam melakukannya, para pemimpin digital harus menampilkan kepemimpinan dengan cara yang berbeda. Inti argumentasi adalah dari fenomena penggunaan digital yang masif dan kemampuan memecahkan masalah secara kreatif . Para pemimpin digital di perguruan tinggi harus menerapkan kepemimpinan yang sangat terkait dengan era persaingan yang begitu keras bahkan substitutif dengan kecerdasan artifisial. Kepemimpinan kreatif dan kepemimpinan digital adalah kunci untuk memungkinkan pemimpin menyajikan secara memadai persiapan bagi semua bawahan untuk berkembang secara digital cluster managerial network. (Bampo et al., 2008)

Inovasi. Sebuah proses kreatif di mana ide-ide baru atau yang lebih baik berhasil dikembangkan dan diterapkan untuk menghasilkan hasil yang praktis dan bernilai (Seaden \& Manseau, 2001). Bagian dari Dari kajian komponen inovasi di industri, ada beberapa istilah definisi yang akan digunakan. Penelitian ini mensintesis teori (Kogabayev \& Maziliauskas, 2017) dan (Lee \& Trimi, 2018) yang menunjukkan komponenkomponen yang digunakan sebagai bentuk inovasi dalam pendidikan tinggi. Makanya, ada komponen terpilih. Mereka adalah 3 komponen sebagai berikut: 1) Inovasi Inkremental, 2) Inovasi Radikal, dan 3) Inovasi Proses. 
Sub komponen incremental innovation terdiri dari 1) Terdapat action plan yang jelas, 2) Adanya perbaikan dan perbaikan dari operasi sebelumnya, 3) Seleksi dan alokasi sumber daya sesuai dengan kriteria yang ditentukan, 4) Melanjutkan sesuai rencana, 5 ) Risiko rendah menentukan.

Sedangkan subkomponen inovasi radikal melibatkan 1) Studi kebutuhan di luar rencana operasi normal, 2) Menciptakan hal-hal yang belum pernah dilihat sebelumnya,

Mempertimbangkan peluang berkelanjutan, 4) Menentukan kerangka kerja untuk berubah sesuai lingkungan, 5) Menentukan risiko tinggi .(Lonsway, 1970)

Subkomponen inovasi proses terdiri dari 1) Menentukan proses administrasi dalam organisasi baru, 2) Menetapkan struktur organisasi baru, 3) Menggunakan teknologi baru untuk menciptakan inovasi, 4) Menggunakan konsep baru, 5) Memperhatikan pengendalian kualitas inovasi, 6) Kurangi prosedur kerja . (Barbosa, 2014)

Kepemimpinan digital seorang "pemimpin digital" tidak hanya memiliki pengetahuan dan penguasaan teknik digital, tetapi juga proses manajemen, bahan, teknik analog, dan seterusnya yang bisa kita temukan di pemimpin desain juga. Apa yang menekankan "digital" dalam kepemimpinan digital, adalah pemahaman yang tajam bagaimana "digital" bisa satu set pemersatu metodologi dan teknologi untuk menyatukan keterampilan dan pengetahuan (Zupanzic et al., 2016). Lebih lanjut disintesis dari beberapa teori (Sheninger, 2019), (Wagner, 2018), (Cingöz \& Akdoğan, 2013), (Becheikh et al., 2006), (Lianto et al., 2018). Penelitian ini telah mensintesis komponenkomponen yang digunakan sebagai bentuk manajemen inovasi pada perguruan tinggi, terdapat 4 komponen sebagai berikut 1) Digital leader vision terdiri, 2) Pengembangan profesional personel, 3) Kompetensi digital, dan 4) Menciptakan jaringan digital.

Sub komponen visi pemimpin digital mengeksplorasi tugas-tugas ini; 1) Menciptakan visi digital, 2) Mengkomunikasikan visi digital, 3) Menerapkan visi digital. Subkomponen Pengembangan profesional personel terdiri dari beberapa peran; 1) Kegiatan Profesional, 2) Menciptakan peluang pembelajaran teknologi digital, 3) Mengukur dan mengevaluasi kinerja digital. Subkomponen kompetensi Digital meliputi 1) Pengetahuan dan pemahaman dalam menggunakan teknologi digital, 2) 
Kemampuan menggunakan teknologi digital untuk manajemen, 3) Mengenali nilai teknologi digital. Subkomponen pembuatan jaringan digital adalah sebagai berikut 1) Kerjasama dengan tujuan, 2) Kegiatan pembelajaran dengan menghubungkan pengetahuan pada jaringan, 3) Komunikasi humas melalui media online.

Kepemimpinan kreatif mengacu pada kemampuan memecahkan masalah dalam norma dan penggunaan yang sesuai. Gaya kepemimpinan ini telah disintesis dari konsep (Francis \& Young, 1979), (Garcia \& Calantone, 2002)

Komponen kepemimpinan kreatif adalah sebagai berikut: 1) Imajinasi, 2) fleksibilitas, dan 3) visi.

Subkomponen imajinasi adalah humor dalam pekerjaan, pemikiran dan opini kreatif, dan intelek. Subkomponen fleksibilitas terdiri dari 1) Kemampuan menemukan jawaban dengan bebas 2) Kemampuan beradaptasi dengan situasi 3) Keterbukaan terhadap ide-ide baru, dan subkomponen visi terdiri dari 1) Menciptakan visi 2) Menyebarkan visi 3) Mematuhi visi.

Hipotesa penelitian ini dikonstruksikan sebagai berikut: H1 :Terdapat pengaruh antara Kepemimpinan Digital terhadap Inovasi (Mihardjo et al., 2019)
H2 :Terdapat pengaruh antara Kepemimpinan Kreatif terhadap Inovasi (Agbor, 2008)

H3 :Terdapat pengaruh bersama kepemimpinan digital dan kepemimpinan kreatif terhadap inovasi (Kozioł-Nadolna, 2020)

Kerangka Berpikir penelitian seperti gambar 1. Dibawah ini :

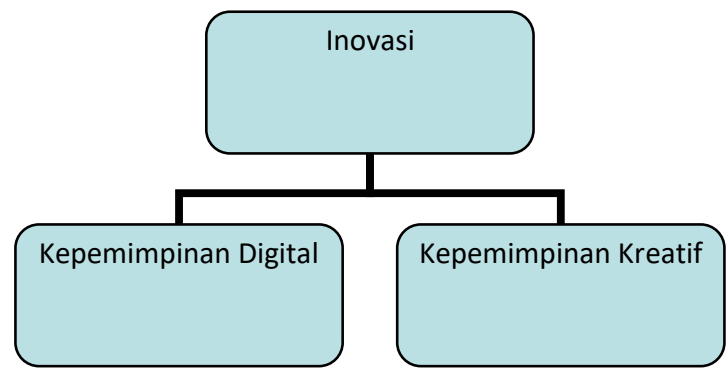

Gambar 1. Kerangka Berpikir

Gambar tersebut menjelaskan dimana kepemimpinan digital dan kepemimpinan kreatif diduga sangat menunjang terbangunnya manajemen inovasi dari institusi UMKM.

\section{METODOLOGI PENELITIAN}

\section{Rencana Kegiatan penelitian} dilakukan di 10 perusahaan UMKM industri . Wilayah mencakup area sekitar Jatimulya Bekasi Jawa Barat. Dimana waktu penelitian dilakukan pada bulan januari 2020.

Ruang Lingkup Penelitian dibatasi hanya pada soal inovasi, kepemimpinan digital, kepemimpinan kreatif. 


\section{Definisi Variabel Operasional}

Inovasi dengan melibatkan beberapa dimensi yang cukup sering diusulkan oleh banyak peneliti seperti : 1) Inovasi Inkremental, 2) Inovasi Radikal, dan 3) Inovasi Proses.

\section{Definisi Variabel Operasional}

Kepemimpinan Digital telah merujuk kepada beberapa dimensi seperti 1) Menciptakan visi digital, 2) Mengkomunikasikan visi digital, 3) Menerapkan visi digital.

\section{Definisi Variabel Operasional} Kepemimpinan Kreatif 1) Imajinasi, 2) fleksibilitas, dan 3) visi.

\section{Sampel dan Tekhnik}

Pengumpulan Data. Untuk jumlah sampel sebesar 90 responden diambil dengan menggunakan metode sampel jenuh atas populasi yang telah ditentukan sesuai area penelitian. Sistem Skala data yang dipergunakan dengan menggunakan skala likert pada sistem wawancara langsung melalui penggunaan kuesioner berupa kumpulan pertanyaan tertutup. Jawaban setiap item instrumen yang menggunakan skala likert mempunyai gradasi dari sangat positif sampai sangat negatif, yang dapat berupa kata-kata, Keperluan analisis kuantitatif, maka jawaban dari penelitian itu dapat diberi skor, misalnya:

1. Sangat Setuju diberi skor 5
2. Setuju diberi skor 4

3. Cukup Setuju diberi skor 3

4. Tidak setuju diberi skor 2

5. Sangat tidak setuju diberi skor 1 yang kemudian akan dilakukan pengembangan instrument penelitian.

Validasi Pengukuran dilakukan melalui beberapa proses filter statistik deskriptif dan inferensial uji cronbach dan AVE.

Model Persamaan Struktural melalui analisis outer loading, inner loading, penetapan model persamaan struktural. Perangkat lunak yang dipergunakan adalah SMART PLS 3.0.

\section{HASIL DAN PEMBAHASAN}

Bagian ini menyajikan temuan penelitian.

Tabel 1. Outer Loading

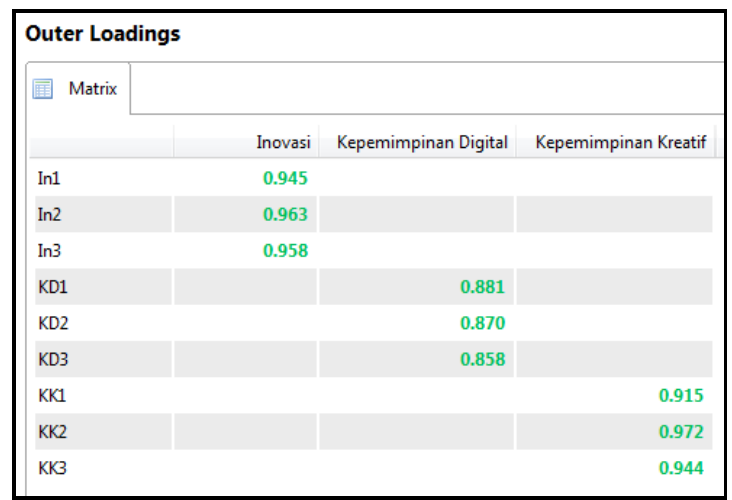

Dari tabel diatas menunjukkan bahwa semua indikator berada diatas $>0.7$ loading factor-nya sehingga bisa dikatakan bahwa seluruh indikator telah merefleksikan dengan baik variabel 
latennya dan juga menunjukkan validitas konvergen yang bisa diterima.(Ghozali \& Latan, 2015)

\section{Tabel 2. Validitas dan Reliabilitas}

\section{Konstrak}

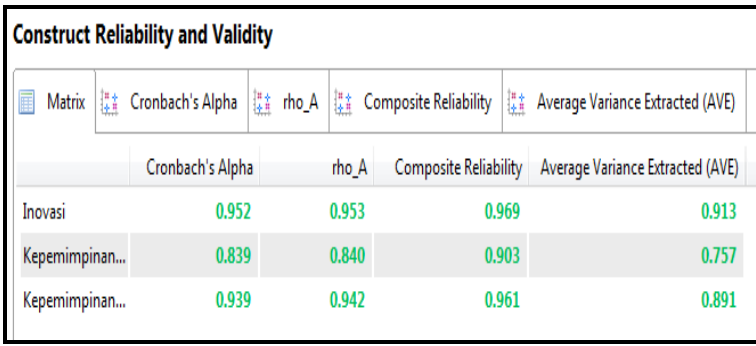

Tabel diatas menunjukkan status data yang reliabel ditunjukkan oleh parameter cronbach alpha lebih besar dari 0.7 (Dr. Ir. Edy Supriayadi, 2014) begitu juga diperkuat oleh parameter composite $>0.7$ dan memiliki validitas yang baik dimana status AVE diatas 0.5 untuk bisa dilanjutkan kedalam analisis outer atau inner model.(Ghozali \& Latan, 2015)

\section{Gambar 2. Analisis Inner Model}

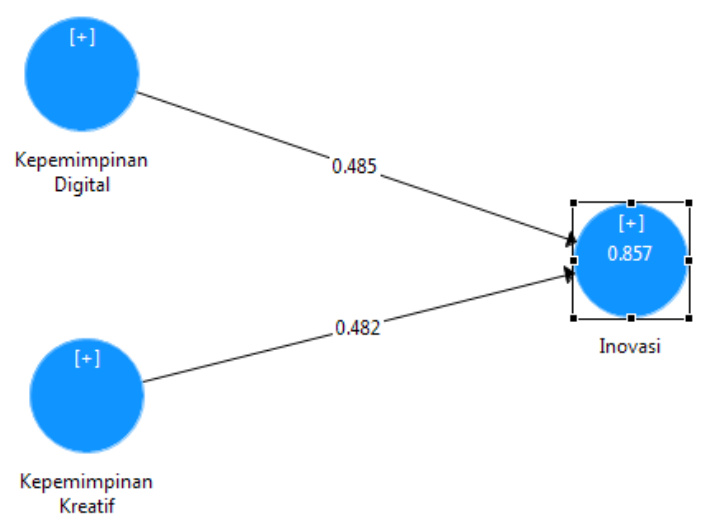

Sebenarnya analisis outer model telah ditunjukkan dengan lugas dan baik oleh semua loading factor yang telah menunjukkan kekuatan merefleksikan semua variabel laten dengan baik. Dengan demikian dapat dikatakan bahwa didalam penelitian ini analisis outer model sudah menyimpulkan dengan baik model yang ditawarkan oleh penulis. Sedangkan untuk analisis inner model seperti yang divisualisasikan oleh gambar 2. Diatas telah menunjukkan dengan jelas bahwa secara parsial kepemimpinan digital 0.485 telah berpengaruh positif. Begitu juga dengan peran parsial kepemimpinan kreatif sebesar 0.482. dan terbukti sangat signifikan, tertera dengan dua-duanya memiliki $\mathrm{p}$ values dibawah 0.05. Pada tabel 3 dibawah berikut.

Tabel 3. Signifikansi Koefisien Jalur

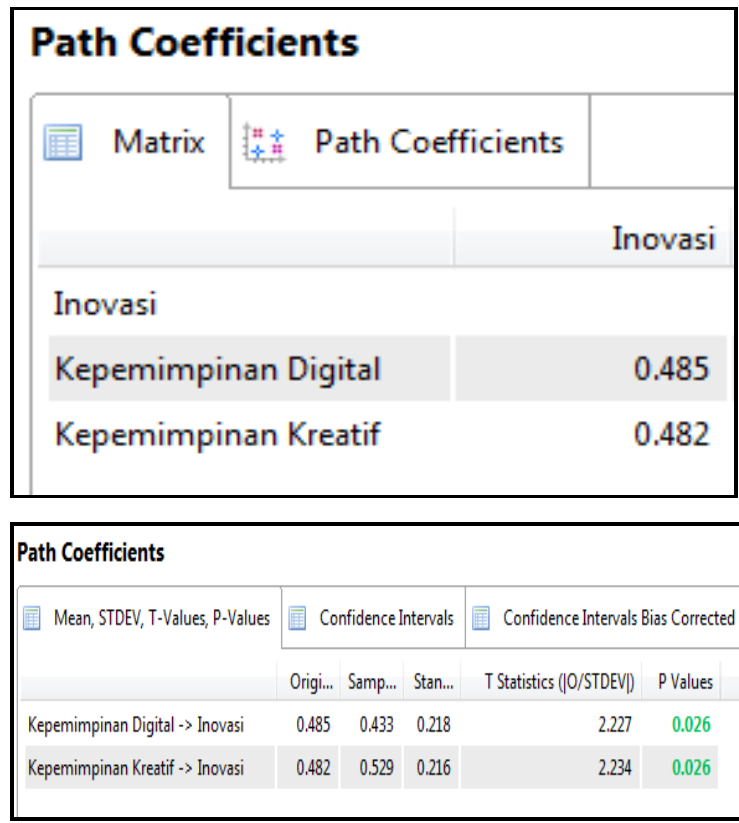

\section{Persamaan Struktural 1}

IN $=0.485 \mathrm{KD}+0.482 \mathrm{KK}$ 
Terlihat bahwa persamaan struktural pertama menjelaskan pengaruh $\mathrm{KD}$ atau Kepemimpinan Digital sebesar 0.485 Jika variabel lain bernilai konstan maka Nilai IN akan berubah sebesar 0,485 setiap satu satuan KD.dan KK atau Kepemimpinan Kreatif sebesar 0.482 Jika variabel lain bernilai konstan maka Nilai IN akan berubah sebesar 0,485 setiap satu satuan KK.

Tabel 5. R kuadrat dan Model Fit

\begin{tabular}{|c|c|c|c|}
\hline \multicolumn{4}{|l|}{ R Square } \\
\hline \multirow[t]{2}{*}{ Matrix } & 㩰桑 R Square & 掉莘 RS & quare Adjusted \\
\hline & & R Square & R Square Adjus... \\
\hline Inovasi & & 0.857 & 0.853 \\
\hline
\end{tabular}

\begin{tabular}{|l|r|r|}
\hline \multicolumn{3}{|l|}{ Model_Fit } \\
\hline \multirow{2}{*}{ Fit Summary } & rms Theta & \\
\cline { 2 - 3 } & Saturated Model & Estimated Mo... \\
\cline { 2 - 3 } SRMR & 0.064 & 0.064 \\
d_ULS & 0.185 & 0.185 \\
d_G & 0.437 & 0.437 \\
Chi-Square & 203.028 & 203.028 \\
\hline NFI & 0.807 & 0.807 \\
\hline
\end{tabular}

Selanjutnya seluruh gambaran variabilitas laten dapat menjelaskan secara kuat dan langsung kepada prediksi variasi inovasi sebesar R square 85\%, (Dr. Ir. Edy Supriayadi, 2014).

Ditemukan juga bahwa secara umum parameter yang ditunjukkan oleh informasi model fit Smart PLS dalam keadaan baik dan mampu diterima sebagai prasyarat model yang cukup baik dimana tertera NFI 0.860. (Dr. Ir. Edy Supriayadi, 2014).

\section{KESIMPULAN}

Dengan demikian sampailah pada kesimpulan akhir pada penelitian ini menunjukkan bahwa terdapat pengaruh yang cukup signifikan antara kepemimpinan digital dan kepemimpinan kreatif terhadap inovasi. Dengan demikian implikasi yang harus ditindaklanjuti manajemen UMKM adalah harus menjamin bahwa proses menciptakan visi digital, mengkomunikasikan visi digital, menerapkan visi digital menjadi sebuah keharusan didalam menghadapi perubahan disrupsi tekhnologi abad 21 ini dilain pihak manajemen juga harus menjamin bahwa proses pembentukan dimensi kepemimpinan kreatif didalam bermajinasi, berkonstruksi fleksibilitas, dan merealisasikan visi merupakan penjamin terbentuknya tingkatan inovasi yang ekstrem radikal.

\section{REFERENCES}

Agbor, E. (2008). Creativity and innovation: The leadership dynamics. Journal of Strategic Leadership, 1(1), 39-45.

Bampo, M., Ewing, M. T., Mather, D. R., 
Stewart, D., \& Wallace, M. (2008). The effects of the social structure of digital networks on viral marketing performance. Information Systems Research, 19(3), 273-290.

Barbosa, E. (2014). Organizational culture oriented for innovation: Influencing variables. Zeszyty Naukowe Małopolskiej Wyższej Szkoły Ekonomicznej w Tarnowie, 2 (25), 37-45.

Becheikh, N., Landry, R., \& Amara, N. (2006). Lessons from innovation empirical studies in the manufacturing sector: A systematic review of the literature from 19932003. Technovation, 26(5-6), 644664.

Cingöz, A., \& Akdoğan, A. A. (2013). Strategic flexibility, environmental dynamism, and innovation performance: An empirical study. Procedia-Social and Behavioral Sciences, 99, 582-589.

Dr. Ir. Edy Supriayadi, M. (2014). spss+amos, statistik data analysis.

Francis, D., \& Young, D. (1979). Improving work groups, a practical manual for team building. University Associates.

Garcia, R., \& Calantone, R. (2002). A critical look at technological innovation typology and innovativeness terminology: a literature review. Journal of Product Innovation Management: An International Publication of the Product Development \& Management Association, 19(2), 110-132.

Ghozali, I., \& Latan, H. (2015). Partial Least Squares, konsep, teknik dan aplikasi menggunakan program Smartpls 3.0 untuk penelitian empiris. Semarang: Badan Penerbit UNDIP.

Kogabayev, T., \& Maziliauskas, A. (2017). The definition and classification of innovation. HOLISTICA-Journal of Business and Public Administration, 8(1), 5972.

Kozioł-Nadolna, K. (2020). The Role of a Leader in Stimulating Innovation in an Organization. Administrative Sciences, 10(3), 59.

Lee, S. M., \& Trimi, S. (2018). Innovation for creating a smart future. Journal of Innovation \& Knowledge, 3(1), 1-8.

Lianto, B., Dachyar, M., \& Soemardi, T. P. (2018). Continuous innovation: a literature review and future perspective. International Journal on Advanced Science, Engineering and Information Technology, 8(3), 771- 
779.

Lonsway, F. A. (1970). ASTIN,

ALEXANDER W. The College En vironment. Washington, DC: American Council on Education, 1968. 187 pp. \$5.00. Journal of Teacher Education, 21(2), 314-315. Mihardjo, L., Sasmoko, S., Alamsyah, F., \& Elidjen, E. (2019). The influence of digital leadership on innovation management based on dynamic capability: Market orientation as a moderator. Management Science Letters, 9(7), 1059-1070.

Nayeri, M. D., \& Rostami, M. (2016). A Model on Knowledge Workers Performance Evaluation. Review of Knowledge Economy, 3(1), 1-13.

Obiekwe, O. (2018). Human capital development and organizational survival: A theoretical review. International Journal of Management and Sustainability, 7(4), 194-203.

Seaden, G., \& Manseau, A. (2001). Public policy and construction innovation. Building Research \& Information, 29(3), 182-196.

Sheninger, E. (2019). Digital leadership:

Changing paradigms for changing times. Corwin Press.

Tong, S., \& Baslom, M. M. M. (2019).

Knowledge management (KM) practices in education and learning: Establishing a knowledge economy in Saudi Arabia. Humanities and Social Sciences Letters, 7(1), 1-9. Wagner, D. J. (2018). Digital leadership. Springer.

Zupanzic, T., Verbeke, J., Achten, H., \& Herneoja, A. (2016). Digital leadership. Complexity, Simplicity, 1, 63-68. 